\title{
Analisis Deformasi Gunung Raung Menggunakan Teknologi Differential Interferometry Synthetic Aperture Radar (DInSAR)
}

\author{
Rani Fitri Febriyanti dan Ira Mutiara Anjasmara \\ Departemen Teknik Geomatika, Fakultas Teknik Sipil dan Perencanaan, Institut Teknologi Sepuluh Nopember (ITS) \\ e-mail: ira@geodesy.its.ac.id
}

\begin{abstract}
Abstrak-Gunung Raung merupakan salah satu gunung api aktif Indonesia yang terletak di bagian timur pulau Jawa. Pada tanggal 24 Juni 2015 citra satelit BMKG mendeteksi adanya peningkatan aktivitas pada gunung Raung yang mengakibatkan terjadinya erupsi pada tanggal 28 Juni 2015. Erupsi yang terjadi menyebabkan adanya perubahan (deformasi) pada permukaan gunung Raung. Deformasi yang ada pada permukaan gunung Raung dapat diukur dengan berbagai teknologi, salah satunya yaitu menggunakan teknologi DInSAR. Dalam penelitian ini pengukuran deformasi pada permukaan gunung Raung dilakukan pengolahan dengan teknologi DInSAR metode two-pass dan three-pass dari tiga buah citra satelit Sentinel-1A bulan Juni 2015, Juli 2015, dan September 2015 serta DEM SRTM 30 meter. Penggunaan dua metode ini digunakan untuk membandingkan hasil pengolahan dari kedua metode tersebut jika diterapkan bersamaan apakah memiliki hasil yang sama atau berbeda. Hasil menunjukkan bahwa metode two-pass dan three-pass teknologi DInSAR dapat di terapkan untuk mengetahui deformasi pemukaan gunung Raung, yang menunjukkan terjadinya deformasi mayoritas ada di kaldera gunung Raung. Dari kedua metode, nilai LOS displacement yang dihasilkan memiliki nilai yang sama pada kaldera bagian utara dan selisih relatif kecil, yakni $1 \mathrm{~mm}$ pada kaldera bagian selatan. Sedangkan perbedaan terdapat pada kaldera bagian timur dan barat, yang memiliki selisih hasil cukup besar, yakni $\sim 40 \mathrm{~mm}$. Metode three-pass interferometry dapat menunjukkan hasil deformasi yang signifikan di banding dengan metode two-pass, yang dapat dilihat di kaldera bagian timur dan barat, jika dikaitkan dengan kondisi geologi gunung Raung yang mengalami aktivitas dari bulan Agustus 2015 hingga awal tahun 2016 menurut laporan PVMBG. Meskipun begitu untuk mengetahui besar nilai deformasi yang akurat perlu dilakukan pengukuran secara langsung di lapangan.
\end{abstract}

Kata Kunci-Deformasi, DInSAR, Gunung Raung, dan Sentinel1 A.

\section{PENDAHULUAN}

$\mathrm{G}$ UNUNG Raung merupakan gunung api aktif dengan puncak tertinggi mencapai $3332 \mathrm{mdpl}$ [1] yang terletak di tiga kabupaten di Jawa Timur, yakni Kabupaten Jember, Kabupaten Banyuwangi, dan Kabupaten Bondowoso. Pada 24 Juni 2015, citra satelit BMKG mendeteksi adanya peningkatan aktivitas pada gunung Raung yang kemudian mengarah pada terjadinya erupsi pada tanggal 28 Juni 2015.

Erupsi pada gunung api disebabkan adanya aktivitas magma seperti uplift sebelum erupsi dan penurunan pada saat erupsi [2] yang dapat menyebabkan terjadinya deformasi pada permukaan gunung api [3]. Pengukuran deformasi permukaan sangat penting untuk memahami proses dari gunung api itu sendiri dan bencana yang disebabkannya, selain itu dapat memberikan wawasan penting mengenai struktur, pipa, dan keadaan dari gunung api itu sendiri [4]. Pada prinsipnya deformasi dari tubuh gunung api dapat berupa penaikan permukaan tanah (inflasi) atau penurunan permukaan tanah (deflasi) [5].

Untuk pengamatan deformasi pada gunung api sendiri ada banyak metode yang dapat dilakukan seperti penggunaan GPS (Global Positioning System), seismometer, dan data survei geofisika lainnya untuk membantu mendeteksi dinamika kegiatan gunung berapi [6], selain itu dapat menggunakan teknologi satelit penginderaan jauh aktif yang menyediakan cakupan global untuk pemantauan gunung api [7].

Differential Interferometry Synthetic Aperture Radar (DInSAR) merupakan teknik berbasis radar yang mengeksploitasi informasi yang ada pada fase, setidaknya dua gambar SAR yang diperoleh pada daerah yang sama, pada waktu yang berbeda, untuk memperoleh pengukuran deformasi pada suatu daerah [8]. Teknik DInSAR dapat digunakan untuk mengukur pergerakan kecil pada suatu wilayah dari waktu ke waktu.

Penelitian deformasi pada permukaan gunung api yang telah dilakukan sebelumnya dengan teknologi DInSAR [9][10] hanya menggunakan metode two-pass interferometry saja, sedangkan pada teknologi DInSAR terdapat metode lainnya, yakni three-pass interferometry. Sehingga dari metode DInSAR yang ada, tidak dapat diketahui jika metode tersebut diterapkan secara bersamaan akan memiliki hasil yang sama atau berbeda. Oleh karena itu pada penelitian studi ini diterapkan teknologi DInSAR metode two-pass interferometry dan three-pass interferometry untuk mendapatkan besarnya deformasi pada permukaan gunung Raung setelah mengalami erupsi yang kemudian dapat di analisis apakah kedua metode tersebut memiliki hasil yang sama atau berbeda.

\section{METODOLOGI PENELITIAN}

\section{A. Lokasi Penelitian}

Lokasi penelitian ini mengambil studi kasus wilayah gunung Raung yang berada di Provinsi Jawa Timur. Pada koordinat $8^{\circ} 4^{\prime}$ LS - $8^{\circ} 12^{\prime}$ LS dan $114^{\circ}-114^{\circ} 10^{\prime \prime}$ BT. Dengan batas wilayah utara dengan Kabupaten Bondowoso, barat dengan Kabupaten Jember, selatan dan timur dengan Kabupaten Banyuwangi 


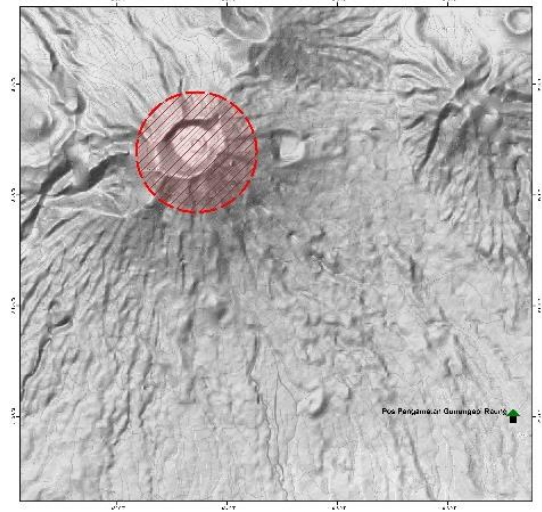

PITA KamaSan BaIIAYA GINGKAT KLGIATAN LEVELI/ TORMAL
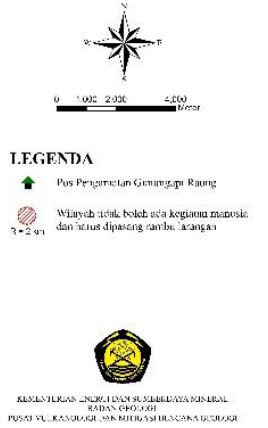

Gambar 1. Lokasi Penelitian (PVMBG, 2014)

\section{B. Data dan Peralatan}

1) Data

Data yang digunakan dalam penelitian ini meliputi :

1. Tiga citra satelit Sentinel-1A menggunakan band-C single polaritation $(\mathrm{VV})$ dengan panjang gelombang $5,6 \mathrm{~cm}$.

2. Data Precise Orbit Ephemeride [AUX_PEORB]

3. DEM SRTM 30 meter

Tabel 1.

Data Citra Sentinel-1A

\begin{tabular}{cccc}
\hline \hline ID_Scene & Tanggal & Level & Arah \\
\hline S1A_IW_SLC_1SS & 18-Juni-2015 & 1.0 (Single & Ascending \\
V_20150618T10492 & & Look & \\
3_.._DD9A & & Complex) & \\
S1A_IW_SLC_1SS & 12-Juli-2015 & 1.0 (Single & Ascending \\
V_20150712T10492 & & Look & \\
4_..._79B4 & & Complex) & \\
S1A_IW_SLC_1SS & 22- & 1.0 (Single & Ascending \\
V_20150922T10492 & September- & Look & \\
7_..._0B30 & 2015 & Complex) & \\
\hline \hline
\end{tabular}

\section{2) Peralatan}

Peralatan yang digunakan dalam penelitian ini meliputi Sistem Operasi Ubuntu 16.04 LTS, Sistem Operasi Windows 7, GMT 5, GMTSAR.

\section{Metodologi Penelitian}

Berikut adalah penjelasan tahapan-tahapan pengolahan data SAR dengan teknologi DInSAR pada flowchart gambar 2, sebagai berikut :

\section{Interferometry SAR Processing}

Tujuan dari proses ini yaitu pembentukan citra interferogram dari sepasang data $S L C$ yang terdiri dari citra master dan citra slave. Metode two-pass terbentuk dua pasang citra, 18Juni-12Juli dan 12Juli-22Sept. Dan metode three-pass terbentuk dua pasang citra, 18Juni-12Juli dan 18Juni-22Sept.

2. Differential Interferometry SAR (DInSAR) Processing

Pada citra interferogram yang telah terbentuk dilakukan proses image filtering dengan menaikkan nilai Signal Noise Ratio (SNR) serta penghapusan efek topografi dengan menggunakan DEM SRTM 30 meter pada sistem koordinat radar.
3. Nilai Koherensi

Hasil dari proses DInSAR memiliki nilai koherensi dengan rentang nilai dari $0-1$. Dimana jika nilai koherensi $=1$ menunjukkan bahwa citra master dan slave pada interferogram benar-benar identik, begitu pula sebaliknya dengan nilai koherensi $=0$. Pada penelitian ini menggunakan nilai koherensi 0,2 .

4. Phase Unwrapping dan Geocoding

Citra dari proses DInSAR masih dalam satuan radian (phase) dalam rentang $-\pi$ sampai dengan $\pi$, sehingga menimbulkan masalah ambiguitas. Pola deformasi sudah dapat terlihat tetapi informasi deformasi belum dapat terbaca dengan baik, sehingga di butuhkan proses phase unwrapping untuk mendapatkan nilai phase absolut dan merubah satuan phase dari radian menjadi metrik. Sedangkan proses geocoding untuk melakukan transformasi koordinat kembali ke geografis.

5. Analisa Deformasi

Tahap analisa ini bertujuan untuk mengetahui terjadi deformasi pada hasil pengolahan SAR dan membandingkan besar deformasi pada permukaan gunung dari pengolahan yang dilakukan dengan metode two-pass dan three-pass.

\section{HASIL DAN ANALISA}

\section{A. Hasil dan Analisa Besar Deformasi Proses DInSAR}

Hasil citra interferogram yang telah dilakukan proses unwrapping di dapatkan nilai deformasi pada permukaan gunung Raung berdasarkan line of sight (LOS).

Untuk mengetahui sebaran deformasi baik kenaikan (inflasi) atau penurunan (deflasi) pada permukaan gunung Raung maka dibuat cross-section, seperti pada gambar :

1. Metode two-pass interferometry

- Pasangan Citra 1 (18 Juni - 12 Juli)

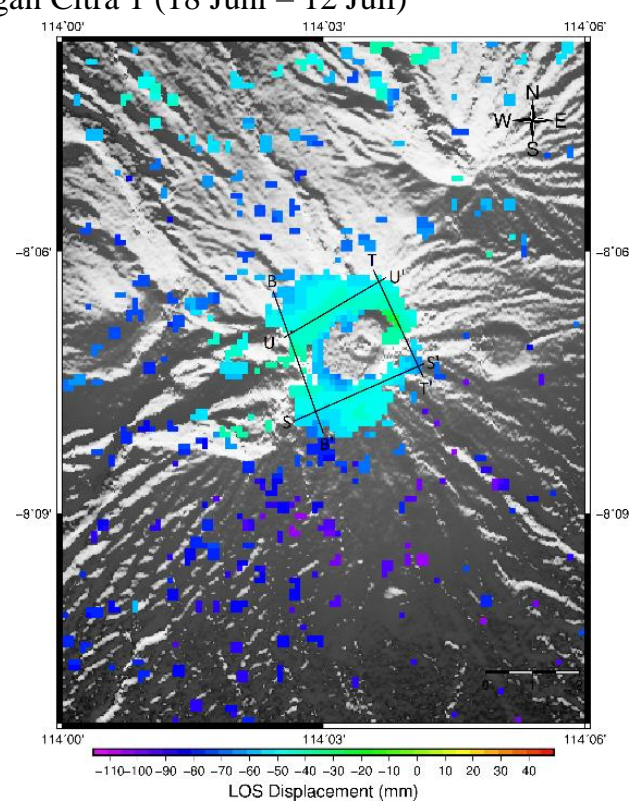

Gambar 2. Peta cross-section pasangan citra 1 (18 Juni - 12 Juli) 
- Pasangan Citra 2 (12 Juli - 22 September)

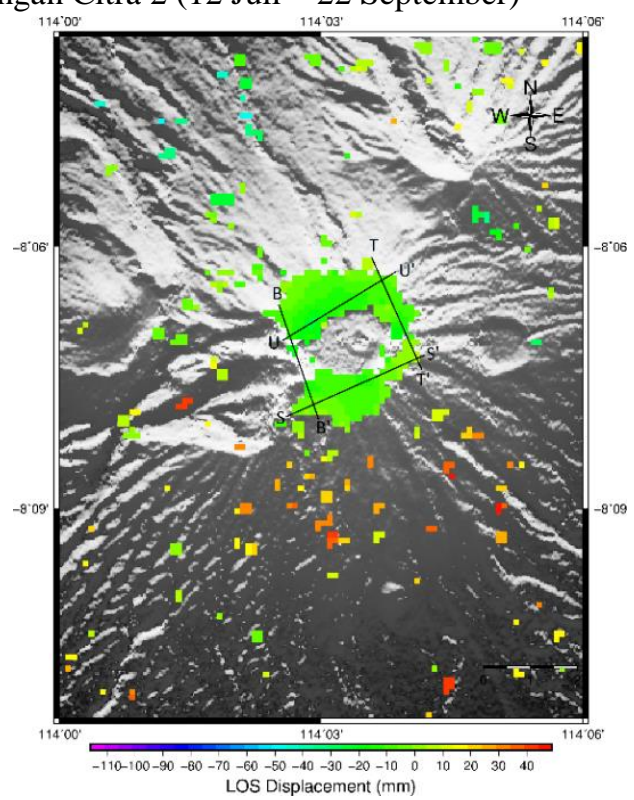

Gambar 3. Peta cross-section pasangan citra 2 (12 Juli - 22 September)

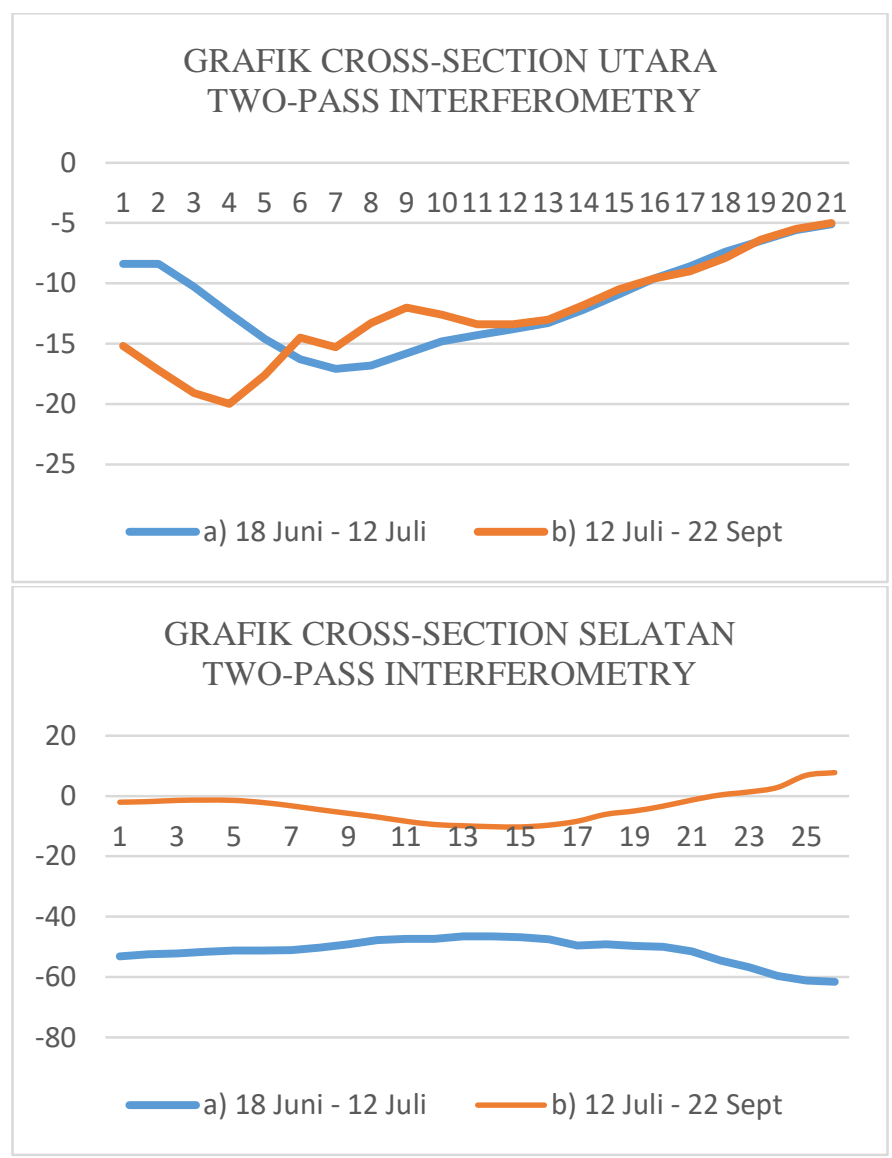

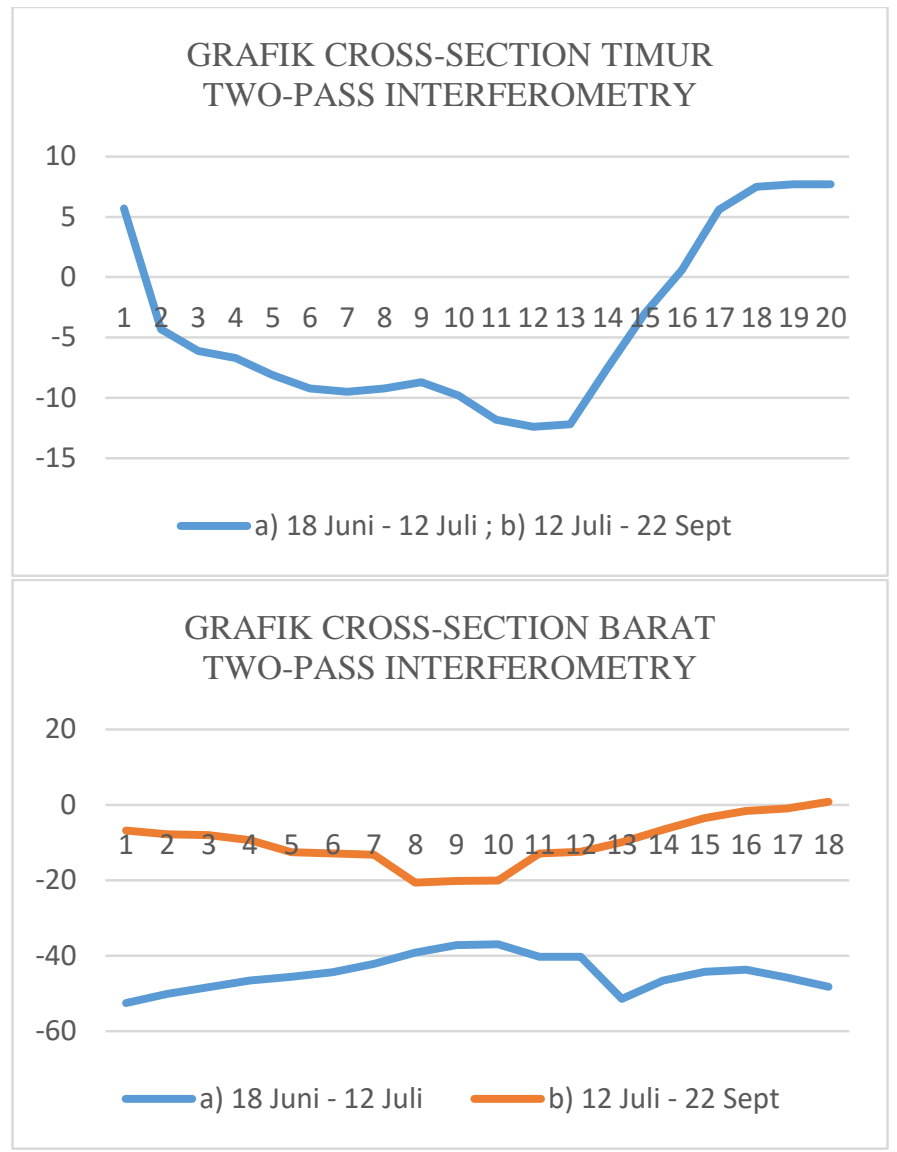

Gambar 4. Grafik cross-section metode two-pass

2. Metode three-pass interferometry

- Pasangan Citra 1 ( 18 Juni - 12 Juli)

Dapat dilihat pada gambar 3.

- Pasangan Citra 2 ( 18 Juni - 22 September)

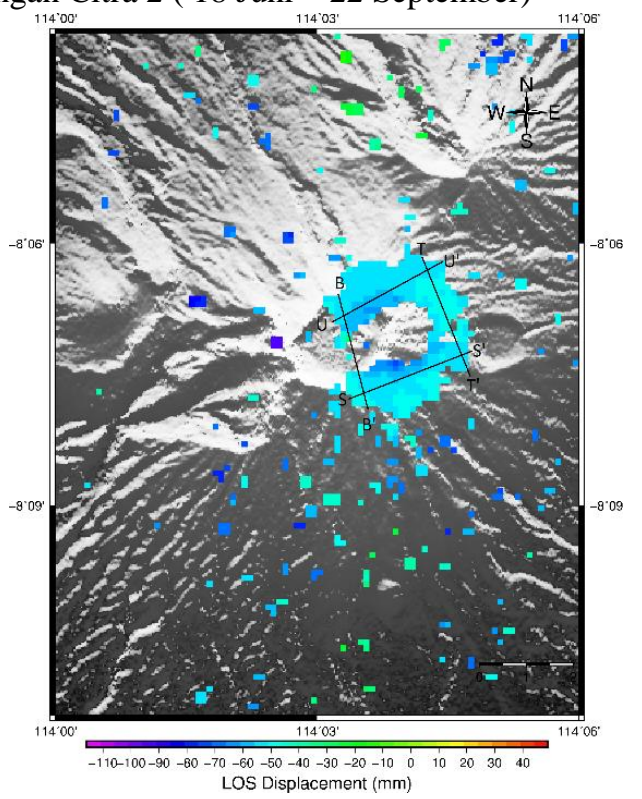

Gambar 5. Peta cross-section pasangan citra 2 (18 Juni - 22 September) 


\section{GRAFIK CROSS-SECTION UTARA THREE-PASS INTERFEROMETRY}$$
0
$$$$
\begin{array}{llllllllllllllll}
1 & 2 & 3 & 4 & 5 & 6 & 7 & 8 & 9 & 10 & 11 & 12 & 13 & 14 & 15 & 16
\end{array}
$$$$
-5
$$

$-10$

$-15$

$-20$

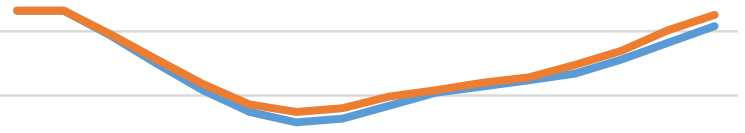

a) 18 Juni - 12 Juli b) 18 Juni - 22 Sept

\section{GRAFIK CROSS-SECTION SELATAN THREE-PASS INTERFEROMETRY}

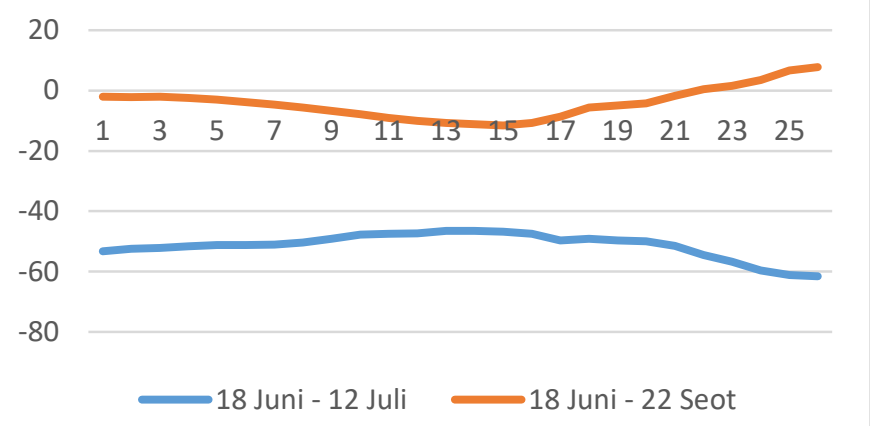

GRAFIK CROSS-SECTION TIMUR

THREE-PASS INTERFEROMETRY

20

0

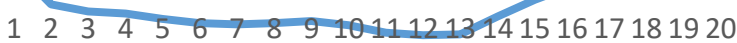

$-20$

$-40$

$-60$

a) 18 Juni - 12 Juli $\longrightarrow$ b) 18 Juni - 22 Sept

\section{GRAFIK CROSS-SECTION BARAT \\ THREE-PASS INTERFEROMETRY}

0

$\begin{array}{lllllllllllllllll}1 & 2 & 3 & 4 & 5 & 6 & 7 & 8 & 9 & 10 & 11 & 12 & 13 & 14 & 15 & 16 & 17\end{array}$

$-20$

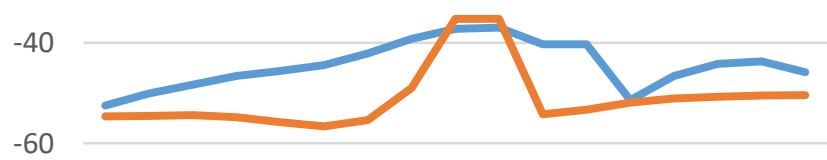

$-60$

a) 18 Juni - 12 Juli

b) 18 Juni - 22 Sept
Pada gambar 2, 3, dan 5 merupakan tiga pasang citra interferogram yang sudah diketahui besar deformasinya beradasarkan LOS dengan rentang nilai scale bar antara -110 $\mathrm{mm} \mathrm{s} / \mathrm{d} 40 \mathrm{~mm}$. Nilai negatif (-) pada scale bar menunjukkan permukaan gunung mengalami deflasi sedangkan nilai positif (+) menunjukkan inflasi. Dari hasil pengolahan 3 pasang citra interferogram dapat dilihat aktivitas deformasi paling dominan terjadi di bagian kaldera gunung.

Pada gambar 4 dan 6 menunjukkan grafik cross-section yang dihasilkan dari metode two-pass dan three-pass, yang dapat disimpulkan bahwa kedua metode tersebut dapat digunakan untuk mengetahui nilai deformasi. Dengan besarnya perbandingan dapat dilihat pada tabel 2 .

Sebagian besar gambar menunjukkan bahwa kaldera gunung mengalami deflasi setelah terjadinya erupsi tetapi ada beberapa titik di bagian kaldera yang menunjukkan inflasi.

Pada tabel 2 dijelaskan bahwa ada perbedaan dari kedua hasil yang diperoleh dari kedua metode tersebut. Pada bagian utara dan selatan kaldera gunung baik pengolahan dengan metode two-pass dan three-pass memiliki nilai deformasi yang hampir sama, dengan selisih yang relatif kecil, yakni $1 \mathrm{~mm}$ pada bagian selatan kaldera. Pada kaldera bagian timur dan barat memiliki nilai deformasi dengan selisih yang sangat besar yakni $40 \mathrm{~mm}$.

Adanya perbedaan hasil dari kedua metode tersebut jelas terlihat karena pemilihan citra master yang berbeda dari tiga pasang citra interferogram yang terbentuk. Selain itu juga dipengaruhi oleh kondisi atmosfer terhadap hasil pengolahan yang belum hilang sepenuhnya sehingga mengakIbatkan adanya noise pada pasangan citra interferogram. Pengaruh atmosfer yang paling berpengaruh yaitu efek dari troposfer. Dimana akibat adanya efek troposfer perambatan gelombang elektromagnetik akan menyebabkan keterlambatan phase yang akan berpengaruh dalam penentuan jarak [8].

Rujukan [11] menjelaskan bahwa dengan keluarnya aliran lava, tekanan pada reservoir magma menurun dan menyebabkan permukaan gunung api menurun. Juga dijelaskan bahwa aktivitas permukaan gunung api secara besar dipengaruhi oleh peningkatan tekanan pada reservoir magma.

Besarnya deformasi yang ada pada kaldera gunung Raung didominasi karena adanya erupsi yang terjadi. Dapat dilihat bahwa pada bagian Selatan dan Barat pasangan citra 18 Juni 12 Juli memiliki nilai deformasi yang besar, yakni $-51 \mathrm{~mm}$ dan $-44 \mathrm{~mm}$. Sedangkan besar nilai deformasi pada wilayah barat dan timur kaldera, memiliki nilai penurunan mencapai $-51 \mathrm{~mm}$, pada metode three-pass. Hal tersebut di atas berhubungan dengan kondisi geologi dari gunung Raung yang dijelaskan pada bagian analisa kondisi geologi gunung Raung. 
Tabel 2.

Perbandingan Besar Deformasi

\begin{tabular}{|c|c|c|c|c|c|c|c|c|}
\hline \multirow{3}{*}{ 造 } & \multicolumn{4}{|c|}{ Two-Pass } & \multicolumn{4}{|c|}{ Three-Pass } \\
\hline & \multicolumn{2}{|c|}{$\begin{array}{c}18 \text { Juni }-12 \\
\text { Juli }\end{array}$} & \multicolumn{2}{|c|}{$\begin{array}{c}12 \text { Juli }-22 \\
\text { Sept }\end{array}$} & \multicolumn{2}{|c|}{$\begin{array}{c}18 \text { Juni }-12 \\
\text { Juli }\end{array}$} & \multicolumn{2}{|c|}{$\begin{array}{c}18 \text { Juni }-22 \\
\text { Sept }\end{array}$} \\
\hline & 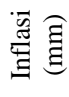 & 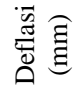 & 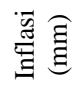 & 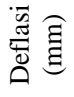 & 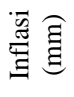 & 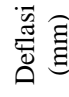 & 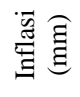 & 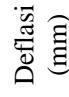 \\
\hline $\mathrm{U}$ & - & -12 & - & -12 & - & -12 & - & -12 \\
\hline $\mathrm{S}$ & - & -51 & 4 & -5 & - & -51 & 4 & -6 \\
\hline $\mathrm{T}$ & 6 & -8 & 6 & -8 & 6 & -8 & - & -51 \\
\hline B & - & -44 & - & -10 & - & -44 & - & -51 \\
\hline
\end{tabular}

\section{1) Koherensi Citra Interferogram}

Koherensi merupakan nilai yang digunakan untuk mengestimasi phase noise dari citra interferogram.

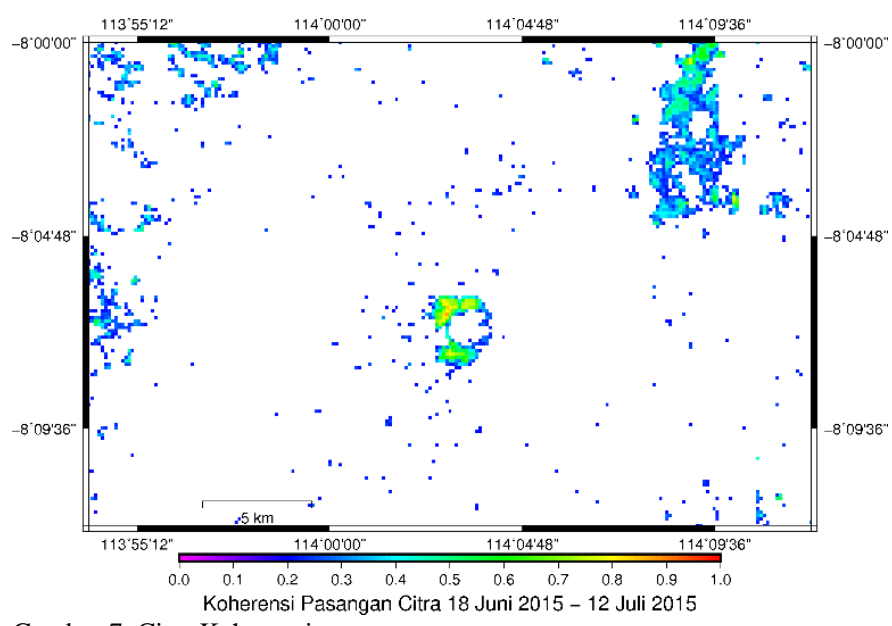

Gambar 7. Citra Koherensi

Pada scalebar warna merah menunjukkan tingkat koherensi yang paling tinggi dan warna ungu menunjukkan tingkat koherensi paling rendah. Pada gambar 8 citra koherensi yang ditampilkan hanya menunjukkan wilayah yang memiliki nilai koherensi di atas 0,2 saja.. Wilayah yang memiliki nilai di bawah 0,2 merupakan wilayah vegetasi dengan kerapatan tinggi. Untuk nilai koherensi yang tinggi berada pada wilayah puncak gunung api.

Rendahnya nilai koherensi pada citra interferogram disebabkan karena wilayah penelitian didominasi vegetaasi dengan kerapatan tinggi. Pada wilayah vegetasi, dekorelasi temporal menyebabkan penurunan nilai koherensi [12], serta hasil penelitian yang sudah dilakukan sebelumnya [13] mengindikasikan bahwa koherensi pada band-C secara signifikan lebih rendah pada area vegetasi dibandingkan urban area dikarenakan interval waktu 12 hari pada pengambilan citra Sentinel-1A dianggap lama jika dibandingkan dengan ERS-1 yang interval waktu pengambilan citra hanya 3 hari saja.

\section{2) Geometri Pencitraan Radar}

Gunung Raung juga memiliki relief topografi yang bervariasi, yang memberikan pengaruh terhadap hasil pencitraan radar. Dikarenakan arah pencitraan radar yang ke samping menyebabkan adanya distorsi pada hasil pencitraan, distorsi berupa layover, shadow, dan forshortening. Distosi pada radar dipengaruhi dua hal yakni incidence angle dan slope pada wilayah pencitraan [8]. Pengaruh dari distorsi akan memberikan efek pada proses unwrapping dan kembalinya sinyal pantul ke sensor radar, yang menyebabkan banyaknya area kosong (blank unwrapping) pada hasil pengolahan.

Banyaknya blank unwrapping pada penelitian ini disebabkan daerah penelitian yang merupakan dataran tinggi dengan tingginya tingkat kerapatan vegetasi yang menyebabkan rendahnya nilai koherensi citra interferogram. Sehingga ketika dilakukan proses phase unwrapping banyak nilai phase yang hilang dan menghasilkan area blank unwrapping.

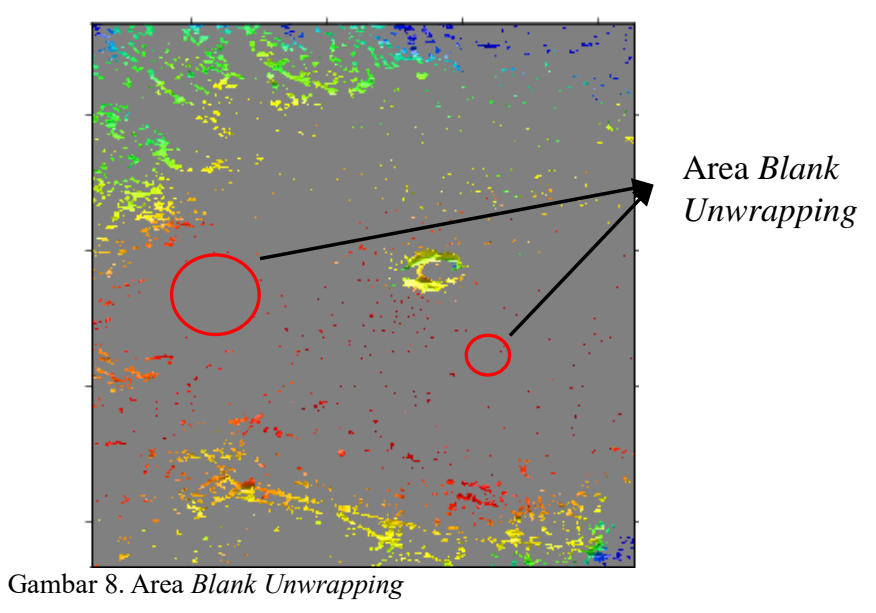

\section{B. Analisa Kondisi Geologi}

Sebagai studi dasar, adanya perubahan terjadi di dalam kaldera gunung disebabkan adanya aktivitas vulkanik selama periode erupsi. Seperti yang dilaporkan Pusat Vulkanologi dan Mitigasi Bencana, sebagai gunung berapi yang paling aktif di Indonesia dengan periode letusan yang pendek, aktivitas gunung Raung saat ini, terletak di bagian bawah kaldera. Dengan karakter erupsi yang dimiliki gunung Raung yakni tipe erupsi eksplosif (Strombolian) seperti yang terjadi pada tahun 1586, 1597, 1638, 1890, 1953, dan 1956 [14].

Erupsi yang terjadi pada tanggal 28 Juni 2015, menurut BNPB dikarakteristikkan sebagai aktivitas strombolian, bergemuruh (roaring), dan lontaran bahan material setinggi 300 meter. Selain itu berdasarkan laporan PVMBG, pada tanggal 1 dan 3-7 Juli adanya lontaran material kembali setinggi 3,7-6,1 km. Pada 5 dan 18 Juli, 1 Agustus, BNPB melaporkan adanya erupsi susulan dengan aktivitas stromboliann [15]

\section{KESIMPULAN}

Berdasarkan hasil analisa deformasi pada permukaan gunung Raung, maka didapatkan beberapa kesimpulan, yaitu :

1. Metode two-pass dan three-pass pada teknologi DInSAR, keduanya dapat di terapkan untuk mengetahui besar nilai deformasi di wilayah permukaan gunung Raung secara general dengan ketelitian sub-centimeter.

2. Pada metode two-pass, besar deformasi berdasarkan LOS displacement pada kaldera bagian utara menunjukkan besar deflasi dengan nilai $-12 \mathrm{~mm}$. Pada kaldera bagian selatan menunjukkan besar deflasi $-51 \mathrm{~mm}$ (pasangan citra Juni- 
Juli) serta menunjukkan inflasi dengan nilai $4 \mathrm{~mm}$ dan deflasi dengan nilai -5 mm (Pasangan citra Juli-September). Pada kaldera bagian timur menunjukkan besar inflasi $6 \mathrm{~mm}$ serta deflasi $-8 \mathrm{~mm}$ (pasangan citra Juni-Juli), dan menunjukkan inflasi dengan nilai $6 \mathrm{~mm}$ serta deflasi dengan nilai -8 mm (Pasangan citra Juli-September). Pada kaldera bagian barat menunjukkan besar deflasi $-44 \mathrm{~mm}$ (pasangan citra Juni-Juli), dan deflasi $-10 \mathrm{~mm}$ (Pasangan citra JuliSeptember)

3. Pada metode three-pass, besar deformasi berdasarkan LOS displacement pada kaldera bagian utara menunjukkan besar deflasi dengan nilai $-12 \mathrm{~mm}$. Pada kaldera bagian selatan menunjukkan besar deflasi $-51 \mathrm{~mm}$ (pasangan citra JuniJuli) serta menunjukkan inflasi dengan nilai $4 \mathrm{~mm}$ dan deflasi dengan nilai -6 mm (Pasangan citra Juli-September). Pada kaldera bagian timur menunjukkan besar inflasi $6 \mathrm{~mm}$ serta deflasi $-8 \mathrm{~mm}$ (pasangan citra Juni-Juli), dan menunjukkan deflasi dengan nilai $-51 \mathrm{~mm}$ (Pasangan citra Juli-September). Pada kaldera bagian barat menunjukkan besar deflasi -44 $\mathrm{mm}$ (pasangan citra Juni-Juli), dan deflasi $-51 \mathrm{~mm}$ (Pasangan citra Juli-September)

4. Metode three-pass interferometry dapat menunjukkan hasil deformasi yang signifikan di banding dengan metode twopass, yang dapat dilihat di kaldera bagian timur dan barat, jika dikaitkan dengan kondisi geologi gunung Raung yang mengalami aktivitas dari bulan Agustus 2015 hingga awal tahun 2016 menurut laporan PVMBG.

\section{UCAPAN TERIMAKASIH}

Penulis R.F.F mengucapkan terima kasih kepada ESA (European Space Agency) yang telah menyediakan data Sentinel-1A untuk keperluan penelitian, Ibu Ira Mutiara Anjasmara, S.T., M.Phil. Ph.D selaku dosen pembimbing yang telah memberikan dukungan dan bimbingan selama penelitian dilaksanakan.

\section{DAFTAR PUSTAKA}

[1] P. V. dan M. Bencana, "Gunung Raung," 2014. [Online]. Available: http://www.vsi.esdm.go.id/index.php/gunungapi/data-dasargunungapi/526-g-raung.

[2] P. Amelung, F., Jonsson, S., Zebker, H., dan Segall, "Widespread uplift and 'trapdoor' faulting on Galápagos volcanoes observed with radar interferometry," Nature, pp. 993-996, 2000.

[3] B. M. Antonielli, B., Monserrat, O., "Pre-eruptive Ground Deformation of Azerbaijan Mud Volcanoes Detected Through Satellite Radar Interferometry (DInSAR)," Tectonophysics, pp. 163177, 2014.

[4] S. Ji, L., Lu, Z., Dzurisin, D., dan Senyukov, "Pre-eruption Deformation Caused by Dike Intrusion Beneath Kizimen Volcano, Kamchatka, Russia, Observed By Insar," J. Volcanol. Geotherm. Res., pp. 87-95, 2013.

[5] A. Suganda, O., Sarsito, D., Abidin, H., dan Kusnandar, "Determinasi Sumber Tekanan dan Analisis Regangan Utama," J. Geol. Indones., vol. 2, no. 2, pp. 73-86, 2007.

[6] K. Chang-Wook, L., Zhong, L., Hyung-Sup, J., dan Oh-Ig, "Surface Displacements of The St. Augustine Volcano, Alaska, Measured From an Dinsar and GPS Data," 7th Eur. Conf. Synth. Aperture Radar, 2008.

[7] R. Rivera, A., Amelung, F., dan Eco, "Volcano Deformation and Modeling on Active Volcanoes in The Philippines From Alos Insar Time Series," Geochemistry Geophys. Geosystems, vol. 17, 2016.

[8] T. A. Mathisen and T. E. S. Hanssen, "The academic literature on intermodal freight transportation," in Transportation Research Procedia, 2014, pp. 611-620.

[9] dan W. Yudha, E., Mulyo , B., Yuwono, "Studi Deformasi Gunung Merapi Menggunakan Teknologi Interferometry Synthetic Aperture Radar (InSAR)," Digilib ITS, 2011.

[10] A. Kusman, "Studi Deformasi Gunung Api Baturdengan Menggunakan Teknologi SAR Interferometri (InSAR)," 2008.

[11] K. Mogi, "Relations between the Eruptions of Various Volcanoes and the Deformations of the Ground Surfaces around them," Bulletin of the Earthquake Research Institutes, 1958.

[12] L. Tamm, T., Zalite, K., Voormansik, K., \& Talgre, "Relating Sentinel-1 Interferometric Coherence to Mowing Events on Grasslands," 2016.

[13] O. Wegmuller, U., Santoro, M., Werner, C., \& Cartus, "On The Estimation and Interpretation of Sentinel-1 TOPS InSAR Coherence," in Proc "Fringe 2015 Workshop," 2015.

[14] R. Arbad, A., Takeuchi, W., Ardy, A., \& Ashari, "Observing Deformation at Mt. Raung East Java Based on PALSAR-2 Imagery by Using Interferometric SAR," in 2nd International Conference of Indonesian Society for Remote Sensing (ICOIRS), 2016.

[15] G. V. Program, "Raung (263340) pada Volcanoes of the World," 2016. [Online]. Available: https://volcano.si.edu/volcano.cfm?vn=263340. 